\title{
A Case Report of 41-Year-Old Female with Fibrous Dysplasia Combined with Ethmoid Mucocele
}

\author{
Seung Heon Kang, Hyunkyung Cha, Seung Cheol Han, and Hyun Jik Kim iD \\ Department of Otorhinolaryngology-Head and Neck Surgery, Seoul National University College of Medicine, Seoul, Korea
}

41세 여자 환자에서 발생한 사골동 점액낭종을 동반한 섬유 이형성증 1 예

강승헌 · 차현경 · 한승철 · 김현직

서울대학교 의과대학 이비인후과학교실

\author{
Received July 3,2020 \\ Revised October 14, 2020 \\ Accepted October 19, 2020 \\ Address for correspondence \\ Hyun Jik Kim, MD, PhD \\ Department of Otorhinolaryngology- \\ Head and Neck Surgery, \\ Seoul National University Hospital, \\ Seoul National University \\ College of Medicine, 101 Daehak-ro, \\ Jongno-gu, Seoul 03080, Korea \\ Tel $+82-2-2072-2203$ \\ Fax $+82-2-745-2387$ \\ E-mail hyunjerry@snu.ac.kr
}

Fibrous dysplasia (FD) is a non-malignant progressive condition, which replaces normal bone and marrow with fibrous tissue and woven bone. Sinus mucocele is a cystic, expansile, and destructive lesion that occurs as a result of obstruction of the sinus ostium secondary to inflammation, trauma, anatomical variation, previous sinus surgery, tumor or FD. Among them, FD combined with mucocele has been rarely reported. Here we report the first case of FD combined with ethmoid mucocele. The patient underwent endoscopic debulking of FD and marsupialization of mucocele. The mucocele was successfully marsupialized, and the patient's symptoms were completely resolved. We propose a new hypothesis that nasal mucosa invaginates into FD and forms a mucocele. For the treatment of ethmoid FD combined with mucocele, we recommend an endoscopic transnasal approach for debulking and marsupialization.

Korean J Otorhinolaryngol-Head Neck Surg 2021;64(8):580-4

Key Words Craniofacial fibrous dysplasia $\cdot$ Ethmoid sinus · Mucocele ·

Transnasal endoscopic surgery.

\section{서 론}

섬유 이형성증(fibrous dysplasia)은 양성, 진행성 병변이며 guanine nucleotide binding protein, alpha stimulating activity polypeptide(GNAS) 유전자의 변이로 인해 정상적인 뼈와 골수를 섬유조직과 무층골로 치환하게 된다.1) 두개안면 골, 대퇴골 근위부, 늑골에서 가장 흔하게 발견되며 단골성, 다골성, 드물게 보고되는 McCune-Albright syndrome(MAS) 으로 나뉜다. 단골성 섬유 이형성증이 전체 유병률의 $75 \%$ $80 \%$ 를 차지하며 그중 약 $10 \%$ 인 두개안면골을 침범하는 경 우 협골상악에서 가장 흔하게 발생한다. 다골성 섬유 이형성 증은 전체의 20\% 25\%의 유병률을 가지며 그 중 50\% 100\%

This is an Open Access article distributed under the terms of the Creative Commons Attribution Non-Commercial License (https://creativecommons.org/licenses/by-nc/4.0) which permits unrestricted non-commercial use, distribution, and reproduction in any medium, provided the original work is properly cited.
에서 두개안면골을 침범하고 $90 \%$ 이상이 두개저 전면부에 서 발생한다. ${ }^{2)}$ 일반적으로 두개안면골을 침범하는 섬유 이형 성증은 진행 속도가 느리다고 알려져 있으나 사춘기 이전의 소아에서는 빨리 진행하여 안구와 치아까지 병변이 침범할 수 있다. $1 \%$ 미만의 경우에서 골육종, 섬유육종, 연골육종 등 으로의 악성변화가 보고된 바 있다. $\left.{ }^{3}\right)$ 그중 부비동 내에 생기 는 섬유 이형성증을 살펴보면 접형동, 사골동, 상악동 순서로 흔하게 발생한다. 주로 코막힘, 두통, 안면통을 호소하며 부비 동염, 후각저하를 동반하는 경우도 흔하다. 섬유 이형성증의 성장이 멈추는 10 대 후반까지 보존적 치료를 하는 것이 권장 되며 수술이 필요한 경우 내시경적 접근법에서부터 고전적인 외부 접근법까지 사용될 수 있다. ${ }^{4}$ 환자의 증상, 주변 주요 구 조물 등을 고려하여 절제 범위를 설정해야 한다.

점액낭종은 상피세포로 둘러쌓인 양성 낭종이며 성장이 느린 병변이다. 부비동구가 막히게 되어 점액질의 부비동 저 
류로 인하여 생기는 것으로 알려져 있고 남녀 동일 비율로 나 타나며 가장 높은 유병률은 30 40대에서 보인다. 그 원인은 염증, 외상, 해부학적 이상, 부비동 수술력, 종양, 그리고 드물게 섬유 이형성증 등으로 인하여 부비동구가 막혀 생기게 된다. ${ }^{5)}$

점액낭종을 동반한 섬유 이형성증은 최근 5년간 소아 4예, ${ }^{6-8)}$ 성인 1 예 ${ }^{9}$ 밖에 보고되지 않은 매우 드문 임상양상이며 병변의 위치에 따라 다양한 임상 증상을 발현한다. 사골동의 병변은 안와, 안와꼭지와 인접해있어 안구 돌출, 복시, 안통증, 시력 저하 등의 다양한 안증상을 일으킬 수 있다. ${ }^{10)}$ 이에 본 증례는 좌측 안구돌출, 안와주위 통증을 주소로 내원한 41세 여자 환자에서 보이는 사골동 점액낭종을 동반한 섬유 이형성증 을 비내시경을 이용한 부비동 조대술을 통하여 성공적으로 치료한 경험을 보고하는 바이다.

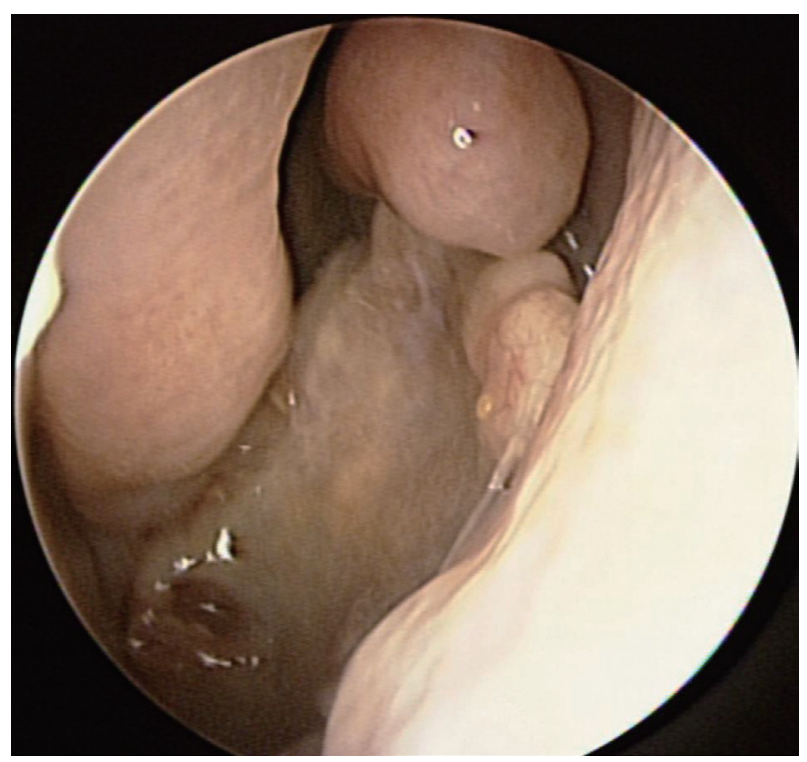

Fig. 1. Endoscopic finding of expansile extruding mass covered with normal mucosa in left middle meatus.

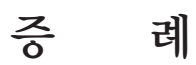

이전 안면 외상, 수술력 포함하여 특이병력 없이 건강하였 던 41세 여자 환자가 15 년 전부터 서서히 악화되는 좌측 안와 주위통, 안구돌출을 주소로 내원하였다. 어지럼증, 사지 위약 감, 실조 등의 신경학적 증상은 부인하였고 이외 다른 비증상, 안증상도 부인하였다. 비내시경 검진상 우측 비중격 만곡증 및 좌측 비강의 중비도에 정상점막으로 덮힌 팽창성 돌출 병 변이 관찰되었다(Fig. 1).

이에 시행한 전산화단층촬영 결과 좌측 사골동을 중심으로 하여 접형동, 익구개와, 익판을 침범한 골성 병변이 관찰되었 다. 병변의 경계는 명확하였고 특징적인 간유리음영(groundglass opacity)을 보여 섬유 이형성증을 의심할 수 있었다. 병 변의 크기는 $7 \mathrm{~cm}$ 에 달하였고 그 내부에는 격막이 쳐진 낭성 병변이 관찰되었다. 병변의 종괴 효과로 인한 좌측 안와 종이 판의 침식과 상악동의 저형성 및 비중격의 우편위가 있었다 (Fig. 2).

이에 점액낭종을 동반한 좌측 사골동 섬유 이형성증으로 진단하였고, 임상증상이 병변의 위치와 상관 관계가 일치하고 점액낭종이 동반되어 있기에 부비동 내시경을 이용한 수술을 계획하여 시행하였다. 전신마취하 내시경 검진 후 좌측 섬유 이형성증 감량술, 점액낭종 조대술 및 좌측 중비도 상악동 개방술(middle meatal antrostomy)을 시행하였다. 특징적인 소견으로 프리어 엘리베이터(freer elevator), 절단 겸자(cutting forceps)로 병변의 전방 격막을 제거하자 한차례 점액낭 종이 조대되었고 이어 미세절삭기(debrider)로 후상방에 위치 한 두 번째 점액낭종의 조대술을 시행하였다. 그 내부에는 갈 색의 점액성 분비물이 가득 차 있었다(Fig. 3).

수술 시 제거된 골편의 조직병리학적 결과에서 특징적인 섬유 이형성증 소견이 확인되었다(Fig. 4). 환자는 수술 후 특 이사항 없이 익일 퇴원하였고, 2달 후 외래에서 시행한 검진상
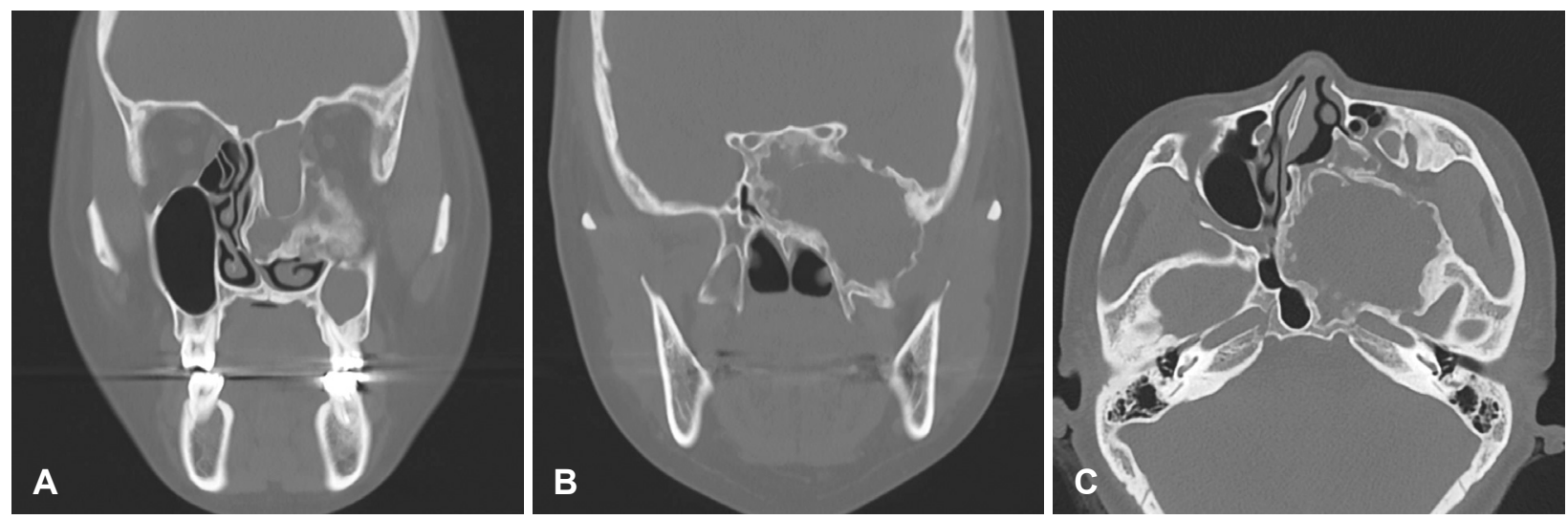

Fig. 2. Left ethmoid fibrous dysplasia combined with mucocele (A) eroded lamina papyracea (B) involvement of pterygoid plates (C) hypoplastic left maxillary sinus and right septal deviation. 

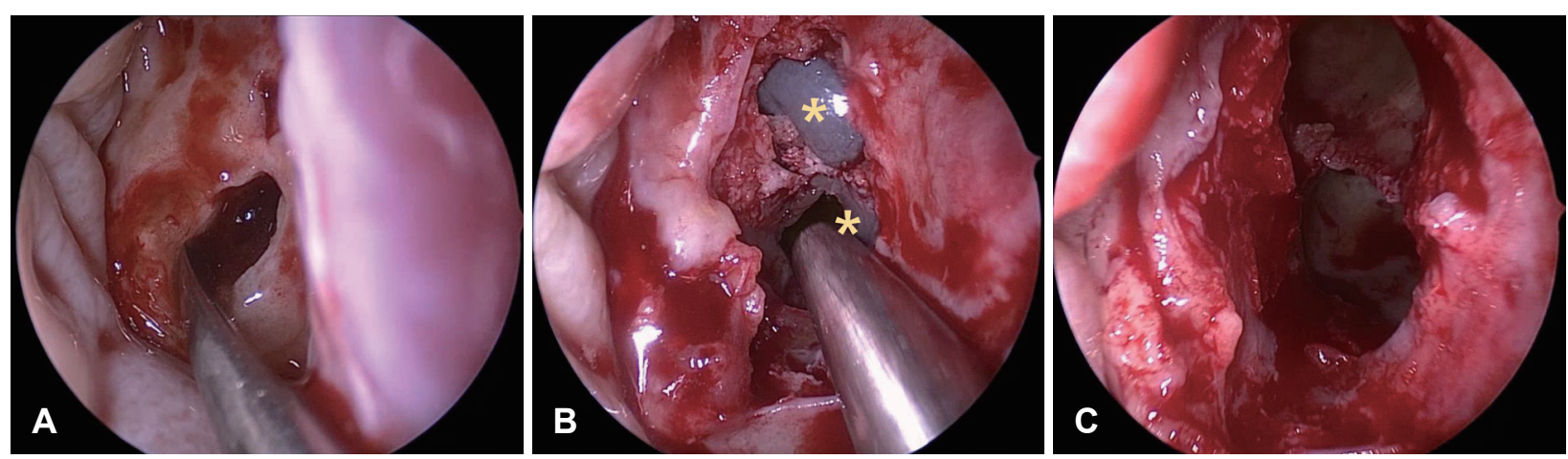

Fig. 3. Endoscopic findings of operation (A) brownish content spilled out from the mucocele (B) visualization of septated mucoceles (asterisks) after removal of anterior wall of fibrous dysplasia (C) after marsupialization.

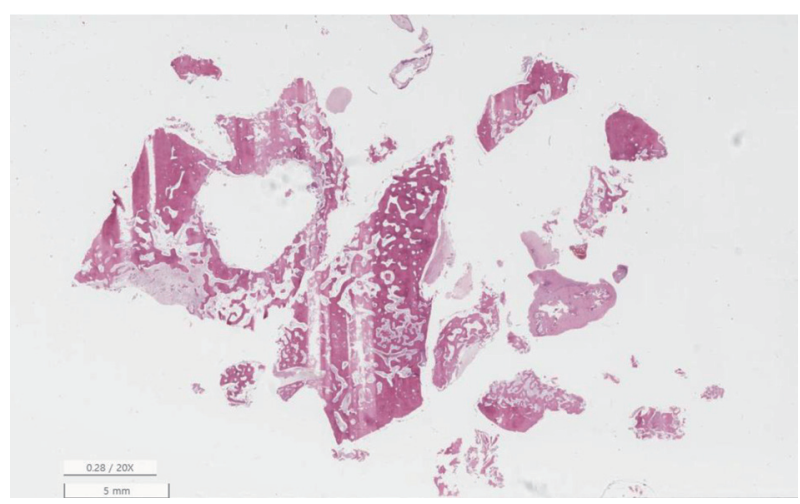

Fig. 4. Histopathologic findings of FD, pathologic report of FD: osteoid trabeculae that are narrow, curvilinear or irregularly-shaped are arranged haphazardly in a background of dense fibroblastic stroma (hematoxylin and eosin, original magnification $\times 20$ ). FD: fibrous dysplasia.

수술 부위는 정상 점막으로 회복되었으며(Fig. 5) 안와주위 통, 안구돌출 증상은 완전히 호전되었다. 수술 후 1년 10개월 까지의 추적 관찰에서도 증상 악화는 없었고 전산화단층촬 영에서도 섬유 이형성증의 진행, 점액낭종의 재발 소견은 관 찰되지 않았다(Fig. 6).

\section{고 찰}

섬유 이형성증은 GNAS 유전자의 변이가 원인인 흔치 않은 골성 병변이다. 섬유 이형성증의 골성 변화는 섬유질로 이루 어져 있고 전산화단층촬영에서 특징적인 간유리음영이 관찰 된다. 전신 골격 어디든 한 곳에만 발생하는 단골성 섬유 이 형성증이 $70 \%$ 를 차지하며 주로 말단 혹은 갈비뼈에 발생한 다. 사춘기가 시작되면 병변의 진행이 멈춘다고 알려져 있다. $30 \%$ 는 다골성 섬유 이형성증이며 여러 뼈에 영향을 미치며 편측성을 띈다. MAS에서는 성조숙증, 피부 색소침착이 함께 발생한다. 두개안면골의 섬유 이형성증은 다골성인 경우가 대부분이며 전두, 접형, 사골, 두정, 측두, 후두골 순서로 흔 하게 발생한다. ${ }^{2}$
점액낭종은 부비동구가 막히게 되면 점액질이 부비동에 저류하게 되어 발생하는 양성 낭종이다. 치료하지 않을 경우 시간이 흐를수록 저류되는 분비물이 많아져 크기가 커지게 되고 주위 구조물에 압력을 주게 된다. ${ }^{2)}$ 점액낭종은 전두-사 골동에 발생하는 경우가 54\% 73\%로 가장 흔하며 위치 및 병변의 진행 정도에 따라 안면통 또는 두통(38\%), 안증상 또 는 안구주위증상(28\%), 무증상(20\%) 등 다양한 임상양상을 보인다. ${ }^{11}$

섬유 이형성증은 임상증상이 있을 경우 수술의 적응증이 되며 점액낭종 역시 수술이 주치료가 된다. 병변의 위치와 병 의 진행 정도에 따라 다양한 수술기법이 적용되며 이는 비내 시경을 통한 비강, 부비강 내 수술에서부터 두개골, 두개저를 포함한 수술이 될 수도 있다. ${ }^{4}$ 점액낭종을 동반한 섬유 이형 성증의 치료에 대해 Derham 등, ${ }^{6}$ Atasoy 등 ${ }^{12}$ 이 전두동의 점 액낭종의 증례를 보고한 바가 있다. 위 문헌에서 섬유 이형성 증에 의해 발생한 골섬유성 변화가 부비동구를 막게 되고 이 로 인해 이차적으로 점액낭종이 발생하는 것으로 그 병인을 이해하였으며, 그 치료로 개두술 및 두개성형술을 시행하였 다. 이후 Koh 등, ${ }^{7)} \mathrm{Wie}$ 등 ${ }^{9}$ 에 의하여 새로운 치료 방법으로 비내시경적 접근을 통해 점액낭종 조대술을 시행한 경험이 보고되었다.

기존의 연구를 종합하여 보면 점액낭종을 동반한 섬유 이 형성증의 치료는 섬유 이형성증의 일반적인 치료방침과 마찬 가지로 환자의 나이, 골 성장여부, 증상을 종합적으로 판단하 여 결정한다. 본 저자 역시 점액낭종이 동반된다고 하더라도 섬유 이형성증이 진행하는 나이에 조대술을 시행하는 것보 다는 환자의 증상이 심하지 않다면 기다려 보는 것이 좋고, 섬유 이형성증이 진행하지 않는 나이에 수술을 진행하는 것 이 수술 후 합병증 및 재발의 가능성을 낮출 수 있다고 판단 한다. 수술적 접근법에 있어서 부비동 내시경 수술 등으로 인 하여 나타나는 점액낭종에 비해 해부학적 기형이 동반되어 있을 가능성이 높아 병변에 대한 접근과 조대를 위한 구멍을 

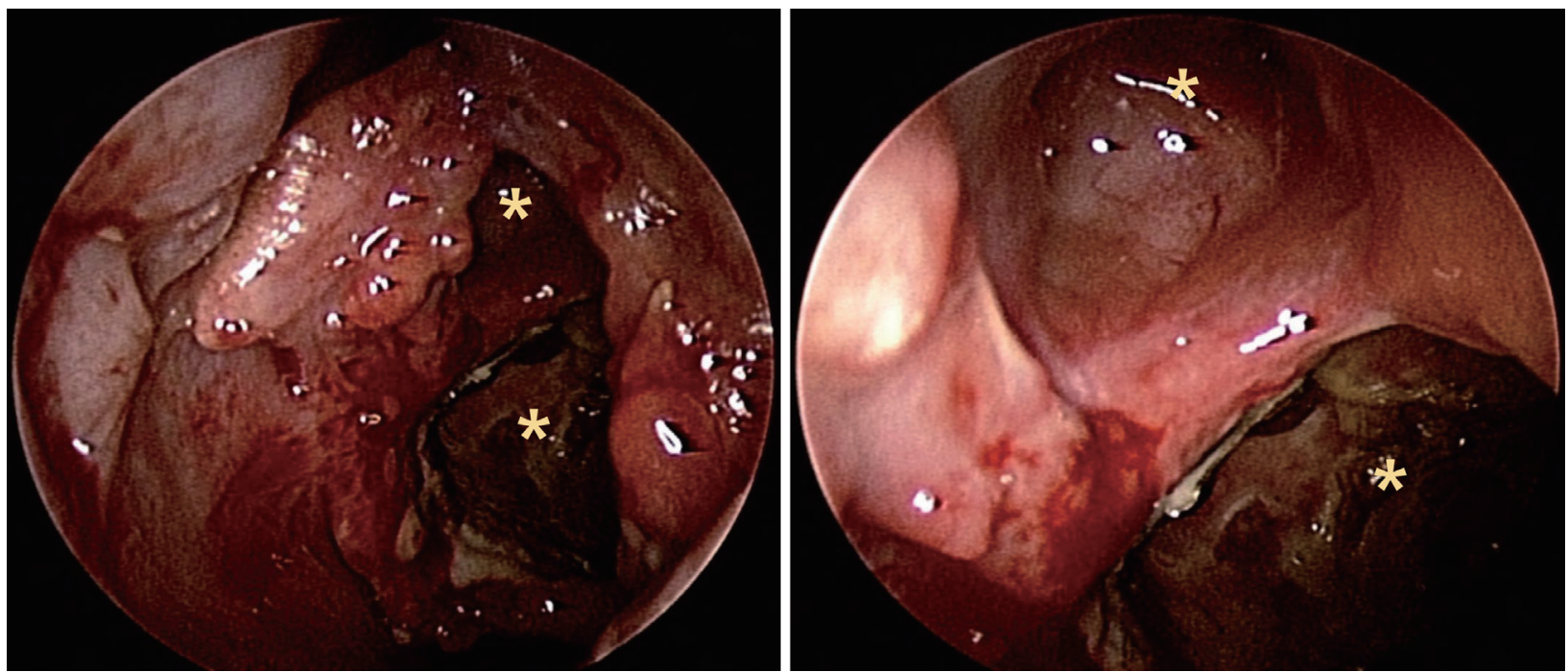

Fig. 5. Endoscopic finding of left sinonasal cavity at postoperative day 2 months. No evidence of recurrence of two septated mucoceles (asterisks).
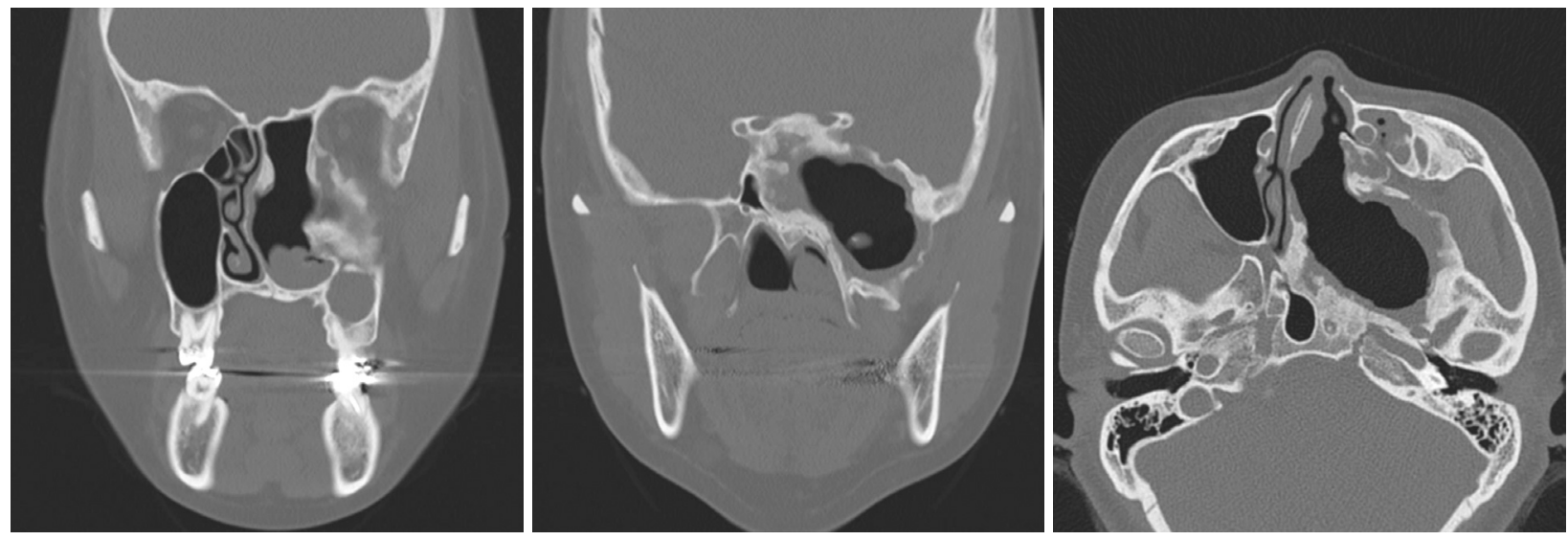

Fig. 6. Postoperative CT scan at postoperative day 1 year and 10 months. Debulked fibrous dysplasia and marsupialized mucoceles compared with Fig. 1.

형성하기 어려울 수 있다. 또한 수술 후 섬유 이형성증이 남 아있거나 진행하는 경우 증상이 완전히 호전되지 않거나 조 대된 구명의 협착이 발생하여 재발률이 상대적으로 높을 수 있어 수술 시 가능한 광범위한 조대술이 필요하다. 또한 수술 후 주기적인 간격의 추적 관찰 및 증상, 회복 정도에 따라 적 절한 약물치료가 증상 조절 및 재발 관찰에 도움이 될 것이 다. 다만 증례 수가 적어 아직 유의미한 비교는 어렵다는 한 계가 있다.

본 증례는 사골동의 점액낭종을 동반한 섬유 이형성증의 환자로, 그 위치는 사골동을 중심으로 전두동, 접형동의 일 부를 침범해 있었다. 안와주위통, 안구돌출 증상을 호소하여 그 치료로 비내시경하 수술을 계획하였다. 섬유 이형성증 내 부에는 2 개의 구획으로 나뉘어진 점액낭종이 존재하였고 이 형성증의 전방 격벽을 제거한 후 점액낭종을 조대하였다. 점
액낭종은 부비동구가 차단되는 것이 그 병인이므로, 기존 보 고된 바와 같이 섬유 이형성증이 원인일 경우 섬유 이형성증 을 감량한 후 이차적인 점액낭종 조대술이 필요하다. 허나 본 증례에서 수술 소견 및 전, 후의 영상학적 소견을 참고하였을 때 점액낭종은 섬유 이형성증의 내부에 온전히 존재하였고 섬유 이형성증의 감량술이 곧 점액낭종의 조대술이 되었다. 이를 통해 섬유 이형성증의 골화 과정에서 비강 점막이 내부 로 함입되고 섬유 이형성증 내부에서 점액질이 저류되어 점 액낭종이 발생할 수 있다는 새로운 병인을 제시한다. 그 치료 로 고전적인 외부 접근법인 아닌 비내시경적 접근만을 통해 점액낭종 조대술을 시행하여 성공적으로 치료하였음을 보고 하는 바이다.

\section{Acknowledgments}

None. 


\section{Author Contribution}

Conceptualization: Seung Heon Kang, Hyun Jik Kim. Data curation: Seung Heon Kang, Hyunkyung Cha, Seung Cheol Han. Formal analysis: Seung Heon Kang, Hyun Jik Kim. Funding acquisition: Seung Heon Kang. Investigation: Seung Heon Kang. Methodology: Seung Heon Kang. Project administration: Seung Heon Kang. Resources: Seung Heon Kang. Supervision: Hyun Jik Kim. Validation: Seung Heon Kang. Visualization: Seung Heon Kang. Writing — original draft: Seung Heon Kang. Writing - review \& editing: Seung Heon Kang.

\section{ORCID}

Hyun Jik Kim ～https://orcid.org/0000-0001-8631-928X

\section{REFERENCES}

1) Weinstein LS, Shenker A, Gejman PV, Merino MJ, Friedman E, Spiegel AM. Activating mutations of the stimulatory $\mathrm{G}$ protein in the McCune-Albright syndrome. N Engl J Med 1991;325(24):168895.

2) DiCaprio MR, Enneking WF. Fibrous dysplasia. Pathophysiology, evaluation, and treatment. J Bone Joint Surg Am 2005;87(8):184864.

3) Sadeghi SM, Hosseini SN. Spontaneous conversion of fibrous dysplasia into osteosarcoma. J Craniofac Surg 2011;22(3):959-61.

4) Lee JS, FitzGibbon EJ, Chen YR, Kim HJ, Lustig LR, Akintoye
SO, et al. Clinical guidelines for the management of craniofacial fibrous dysplasia. Orphanet J Rare Dis 2012;7(Suppl 1):S2.

5) Capra GG, Carbone PN, Mullin DP. Paranasal sinus mucocele. Head Neck Pathol 2012;6(3):369-72.

6) Derham C, Bucur S, Russell J, Liddington M, Chumas P. Frontal sinus mucocele in association with fibrous dysplasia: Review and report of two cases. Childs Nerv Syst 2011;27(2):327-31.

7) Koh LT, Pollaers K, Dhepnorrarat CR. Frontal sinus mucocele in association with polyostotic fibrous dysplasia: A case report. Proc Singapore Healthc 2019;28(3):208-10.

8) Zaki Z, Belcaid A, Alami MN. A rare cause of craniofacial pain in children. Eur Ann Otorhinolaryngol Head Neck Dis 2013;130(1): 36-8.

9) Wie CE, Hong SL, Mun SJ, Cho KS. Endoscopic marsupialization of frontoethmoid mucocele with underlying craniofacial fibrous dysplasia. J Craniofac Surg 2015;26(1):e73-4.

10) Tseng CC, Ho CY, Kao SC. Ophthalmic manifestations of paranasal sinus mucoceles. J Chin Med Assoc 2005;68(6):260-4.

11) Devars du Mayne M, Moya-Plana A, Malinvaud D, Laccourreye O, Bonfils P. Sinus mucocele: Natural history and long-term recurrence rate. Eur Ann Otorhinolaryngol Head Neck Dis 2012;129(3):12530.

12) Atasoy C, Ustüner E, Erden I, Akyar S. Frontal sinus mucocele: A rare complication of craniofacial fibrous dysplasia. Clin Imaging 2001;25(6):388-91. 